\title{
NAJDOU MAGNÓLIE UPLATNĚNÍ V MODERNÍ MEDICÍNĚ?
}

\author{
Jiř́ Patočka
}

10: $1-246,2008$

ISSN 1212-4117

Jihočeská univerzita v Českých Budějovicích, Zdravotně sociální fakulta, katedra radiologie a toxikologie.

Magnólie vynikají bohatostí a velikostí květů, jejichž barva se mění od čistě bílé, přes nejrůznější odstíny žluté a růžové až po červenou či fialovou. Zejména asijské druhy upoutávají svou krásou, protože kvetou ještě před olistěním. V Evropě jsou magnólie známy především jako okrasné rostliny, východní národy si však cení magnólií také jako léčivých rostlin (Patočka et al. 2008). V současné době probíhá intenzivní botanický výzkum magnólií, které vykazují mnoho zajímavých biologických vlastností a prrinášejí zásadní otázky vymezení samotného rodu Magnolia (Jakl, 2004). Ruku v ruce s botanickým výzkumem probíhá i výzkum farmakologický.

Usušená a rozdrcená kůra magnólií (Magnoliaceae), zejména druhů $M$. obovata a $M$. officinalis, je po staletí využívanou drogou tradiční japonské herbální medicíny Kampo i tradiční čínské medicíny. Evropská a americká medicína se o tuto drogu začala zajímat poté, co v ní byly nalezeny bifenylové polyfenoly magnolol a honokiol a difenyletherický lignan obovatol (obr. 1) a byl zjištěn jejich anxiolytický účinek (Patočka et al., 2006). Anxiolytika jsou skupinou látek, které pozitivně ovlivňují afektivitu, odstraňují psychické napětí, strach a úzkost a zlepšují náladu. Anxiolytika jsou vủbec nejčastěji používanou skupinou psychofarmak. Nejznámější skupinou anxiolytik syntetického původu jsou benzodiazepiny. Jejich obliba mezi pacienty je značná, nicméně některé jejich nežádoucí účinky, jako je psychická a fyzická závislost a rychle stoupající tolerance, vedou ke snaze nahradit je méně nebezpečnými léky. Dlouhodobé užívání benzodiazepinů vede k poruchám paměti, zejména v kombinaci s alkoholem. Účinek větších dávek se projevuje únavou a ospalostí, tupě euforickou náladou, poruchami koordinace pohybů a setřelou řečí. Dochází $\mathrm{k}$ útlumu dechového centra a poklesu krevního tlaku; kombinace s jinými farmaky, která tlumí CNS, nebo s alkoholem může být i smrtelná. Nevhodné je rovněž jejich užívání u starších lidí, které často vede ke zmatenosti a ztrátě orientace.

Když bylo zjištěno, že anxiolytický efekt farmakologicky účinných obsahových látek magnólií - magnololu, honokiolu a obovatolu je srovnatelný s efektem benzodiazepinů, začala se o ně zajímat moderní farmakologie (Patočka et al., 2002). Navíc bylo prokázáno, že nemají nežádoucí účinky benzodiazepinů, tj. vznik psychické a fyzické závislosti a rychle stoupající toleranci. Protože tyto látky zvyšují syntézu acetylcholinu $\mathrm{v}$ mozku a stimulují uvolňování tohoto neuromediátoru na synapsích, mohou tak posilovat cholinergní inervaci a zlepšovat kognitivní funkce mozku (Hou et al., 2000).

Protože jsou to látky snadno dostupné synteticky, staly se předmětem mnoha farmakologických studií a byly tak objeveny i další, dříve netušené biologické účinky (Patočka et al., 2006). Z dobře doložených farmakologických účinků magnololu, honokiolu a obovatolu lze kromě jejich anxiolytického účinku uvést:

- schopnost tlumit akutní bolest při zánětu (Lin et al., 2007)

- schopnost chránit tkáň myokardu před oxidativním stresem při infarktu myokardu (Chang et al., 2007)

- významně snižovat kožní projevy alergické reakce u IgE-indukovaných alergických nemocí (Han et al., 2007)

- snižovat aktivitu UDP-glukuronosyltransferázy (UGT) a superoxiddismutázy (SOD) a současně inhibovat klastogenicitu vyvolanou účinkem ionizačního záření (Saito et al., 2008)

- inhibovat buněčnou proliferaci a indukovat apoptózu $\mathrm{v}$ různých rakovinných buňkách (Huang et al., 2007)

- schopnost působit jako anti-atherogenní látky (Kim et al., 2007) a chránit cévy před aterosklerózou (Ou et al., 2007) 
- chránit kưži před stárnutím vyvolaným světlem inhibicí NF-kappaB (Tanaka et al., 2007)
- blokovat dělení buněk nádoru lidské prostaty v G0-G1 fázi (Hahm a Singh, 2007)

Obr. č. 1 Chemické strukturní vzorce farmakologicky nejvýznamnějších polyfenolů z kůry magnólií (Magnolia): magnololu, honokiolu a obovatolu
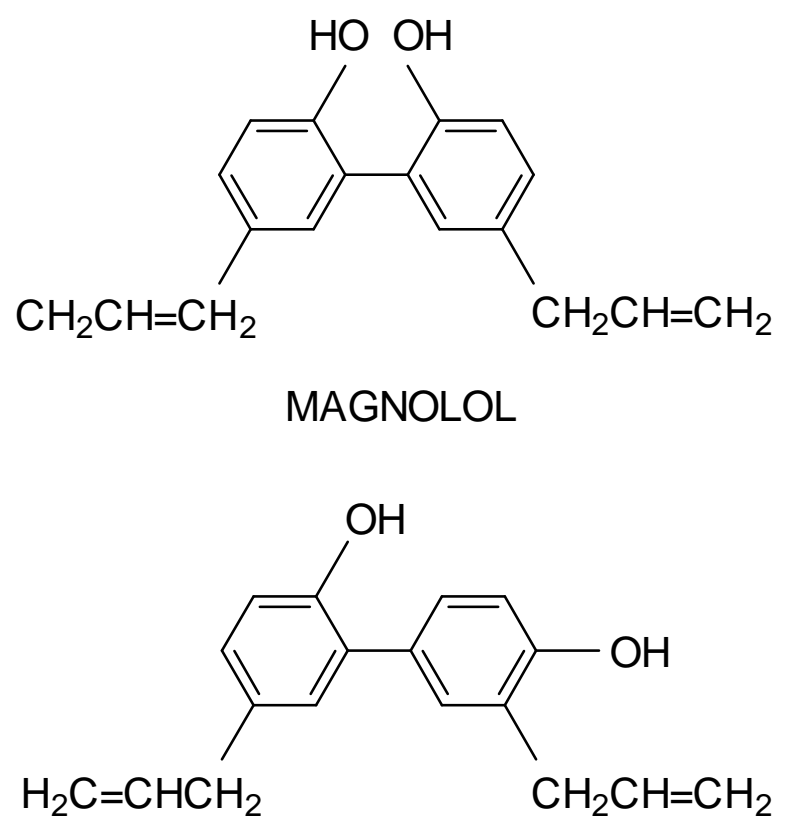

HONOKIOL

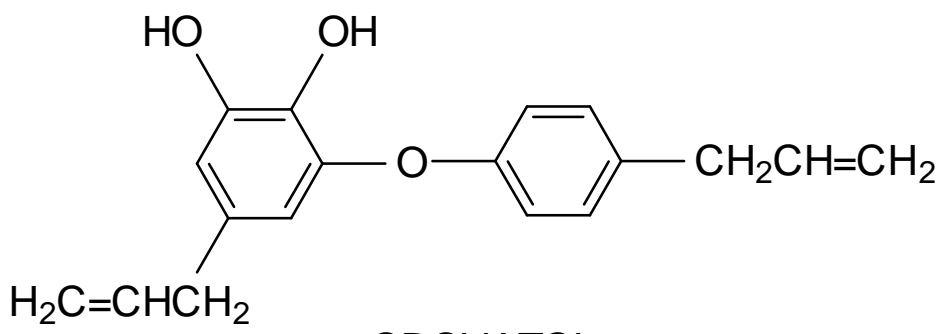

OBOVATOL

Praktickou aplikaci výzkumu magnólií by mohla být žvýkačka s obsahem extraktu z kůry, která inhibuje růst ústní patologické mikroflóry, omezuje pach z úst a zlepšuje hygienu ústní dutiny (Greenberg et al., 2007). Pokusy in vitro prokázaly, že $0,2 \%$ extrakt $z$ kưry magnólií rychle zabijí bakterie Streptococcus mutans, podílející se na vzniku zubního kazu, a bakterie Porphyromo- 
extraktu z kůry magnólií bylo zjištěno, že po 30 minutách se sníżil počet bakterií $\mathrm{v}$ ústech o 61,6 \%, zatímco žvýkačka s obsahem mentolu redukovala počet bakterií jen o 3,6\% (Greenberg et al., 2007). Lze se tedy nadít, že „magnóliová žvýkačka“ se brzy objeví na trhu a stane se významným prostředkem pro zlepšení ústní hygieny.

\section{LITERATURA}

GREENBERG, M., URNEZIS, P., TIAN, M.: Compressed Mints and Chewing Gum Containing Magnolia Bark Extract Are Effective against Bacteria Responsible for Oral Malodor. J Agric Food Chem. 2007, Vol. 55, no 23, s. 9465-9469.

HAHM, E.R., SINGH, S. V.: Honokiol causes G0-G1 phase cell cycle arrest in human prostate cancer cells in association with suppression of retinoblastoma protein level/phosphorylation and inhibition of E2F1 transcriptional activity. Mol Cancer Ther. 2007, Vol. 6, no. 10, s. 2686-2695.

HAN, S. J. et al.: Magnolol and honokiol: inhibitors against mouse passive cutaneous anaphylaxis reaction and scratching behaviors. Biol Pharm Bull. 2007, Vol. 30, no 11, s. 2201-2203.

HOU, Y. C., CHAO, P. D., CHEN, S. Y.: Honokiol and magnolol increased hippocampal acetylcholine release in freely-moving rats. Am J Chin Med. 2000, Vol. 28, no 34, s. 379-384.

HUANG, S. H. et al.: Mechanisms for the magnololinduced cell death of CGTH W-2 thyroid carcinoma cells. J Cell Biochem. 2007, Vol. 101, no 4, s. 1011-1022.
CHANG, C. K. et al.: Oxidative stress and ischemic injuries in heat stroke. Prog Brain Res. 2007, Vol. 162, s. 525-546.

JAKL, J.: Magnólie-nevinná a půvabná. Živa 2004, Vol. 70, no 1. s. 20-22.

KIM, H. M. et al.: Inhibitory role of magnolol on proliferative capacity and matrix metalloproteinase- 9 expression in TNF-alpha-induced vascular smooth muscle cells. Int Immunopharmacol. 2007, Vol. 7, no 8, s. 1083-1091.

LIN, Y. R. et al.: Effects of honokiol and magnolol on acute and inflammatory pain models in mice. Life Sci. 2007, Vol. 8, no 13, s. 1071-1078.

OU, H. C. et al.: Protective effects of magnolol against oxidized LDL-induced apoptosis in endothelial cells. Arch Toxicol. 2007, Vol. 8, no 6, s. 421-432.

PATOČKA, J., JAKL, J., STRUNECKÁ, A.: Expectations of biologically active compounds of the genus Magnolia in biomedicine. J Appl Biomed. 2006, Vol. 4, no 4, s. $171-178$.

PATOČKA, J., JAKL, J., STRUNECKÁ, A.: Magnólie v zahradě i lékárně. Vesmír 2008, Vol. 87, no 2, s. 108 109.

PATOČKA, J., STRUNECKÁ, A., JAKL, J.: Magnolie mohou být nejen krásné, ale i užitečné. Psychiatrie 2002; 6(4): 247-251.

SAITO, J., SHIBUYA, K., NAGASE, H. Anti-clastogenic effect of magnolol on benzo(a)pyrene-induced clastogenicity in mice. Food Chem Toxicol. 2008, Vol. 46, no 2, s. 694-700.

TANAKA, K. et al.: Magnolia obovata extract and its active component magnolol prevent skin photoaging via inhibition of nuclear factor kappaB. Eur J Pharmacol. 2007, Vol. 565, no 1-3, s. 212-219. 